\title{
Apple Varieties Grown in Iowa, 1800-1970
}

\author{
Harry E. Nichols
}

THE APPLE WAS INTRODUCED into America by some of the first settlers along the eastern seaboard. Later, scion wood of some of the varieties grown in Europe and England was imported and grafted into seedling trees. During colonial days, the home orchard became very popular. Long before the Revolutionary War, the first nursery was established on Long Island, the Prince Nursery.

During the years following the Revolutionary War, as people migrated westward over the Alleghenies to the Ohio River valley, they took apple seed with them. Even before all of this area was settled, some people such as Jonathan Chapman, better known as Johnnie Appleseed, planted apple seed in many places along the Ohio River and some of its tributaries, especially in Indiana. About the first thing the pioneer settler did, once he had cleared a plot of ground for a home, was to plant an orchard.

During the early days of settlement when the population was primarily rural, most people grew their own fruit. As towns and cities developed, the need for larger orchards grew. Commercial orcharding started first near the larger towns in the East in the early 1830 s. These larger plantings were gradually extended westward. Large orchards were planted in southern Ohio, and later some of the fruit was transported by boat down the Ohio and Mississippi rivers to New Orleans. The apple barrel came into common use as a container to ship the fruit.

The Apple in Early Iowa

Many years before what is now Iowa was opened for settle- 
ment a few apple trees had been planted. Just who planted the first apple tree west of the Mississippi is not clear. In 1783, Julian Dubuque settled near the present city of Dubuque and engaged in mining lead along with some farming. He died in 1810 . Sometime during this period he, or one of his associates, planted at least one apple tree. It was perhaps the first apple tree planted in Iowa soil. In 1835 this tree was reported to be still producing large crops of apples. The tree was no doubt a seedling tree, and the exact year it was planted is not known.

Credit for the first apple orchard planted in what is now Iowa goes to Louis Honoré Tesson. He established an Indian trading post near the present town of Montrose, in Lee County, land that at the time belonged to Spain. On returning to the area from St. Louis in 1799, he stopped at St. Charles, Missouri and purchased one hundred seedling apple trees which he planted near his trading post, not far from the river. Not long after this, Tesson left the Montrose area, but some of the trees survived and produced fruit for many years. As late as 1870 some of the early natives recall eating fruit from these trees-as the Indians did before them. The last of these trees was finally cut down about 1895 . The Mississippi River has covered the site of the first orchard in Iowa since the building of the Keokuk dam. In 1930 a monument commemorating this orchard was placed in the northwest corner of the school house grounds on old U.S. Highway 61 . The monument consists of a huge boulder with a suitable inscription.

Other apple trees were soon planted on the west side of the Mississippi River. Antoine LeClaire planted an orchard of 400 trees in what is now part of Davenport, soon after the Black Hawk War. These trees were brought by boat from Cincinnati, Ohio. After the first fifty-mile-wide strip of land west of the river was opened for settlement on June 1, 1833, a big demand for apple trees soon developed. Many of these early settlers grew seedling trees, but much of the stock came from the East by boat and consisted of varieties grown there at that time.

In 1845 or 1846 Solomon Berkley planted the first commercial orchard in Iowa, according to a grandson of Mr. Berkley. This orchard of ten acres was planted one mile west of Montrose. The trees were shipped by boat from Buffalo, N.Y., by canal to the Ohio River, down the Ohio and then up the Mississippi to Montrose. There were many seedling trees included which were later 
grafted to a type named Rome Beauty. This orchard was finally cut down sometime in the 1880 s.

Nursery stock shipped by boat was high priced, and soon several nurseries were started in eastern Iowa to supply the growing demand. Iowa's first nursery was established by Robert Avery just west of Burlington in 1836. He had purchased government land and moved from Illinois in 1835. Robert and his son operated this nursery for over forty years. In 1838 the Leonard brothers started another nursery north of Burlington.

The Lewelling brothers, Henderson and John, started a nursery at Salem in Henry County in 1837 . For several years they furnished apple trees to the settlers in that area. They only stayed in Iowa for a few years. In 1845 Henderson decided to go west. He carried live trees in a covered wagon across the Plains to Oregon where he established the first nursery in the Pacific Northwest, near Portland. ${ }^{1}$ His brother, John, followed him the next year, bringing seeds of various fruits. From some sweet cherry seeds he had brought, a seedling tree grew which later was named for one of his Chinese workmen, Bing. The Bing today is the leading variety of sweet cherry grown in the United States.

The first nursery in Lee County was established in 1841 near Denmark by R. Brackett. He had lived near Cincinnati, Ohio and the fall before he and his son, Gustavus B., gathered apple seed from nearby cider mills. This they planted soon after reaching their new home in Iowa. They purchased some named varieties from the Lewelling nursery and used them to graft onto some of their seedling trees. This nursery was maintained for many years. When the Civil War started, Gustavus joined the Union forces and later became a Colonel, serving as Chief of Engineers under General Grant and as a topographical engineer with General Sherman on his march from Atlanta to the sea in 1864. After the war he returned to Denmark and operated the nursery for many years. As many as 200 different varieties were grown there.

Another early nurseryman was Suel Foster, who established

'H. E. Nichols, "Pioneers in Iowa Horticulture," The Palimpsest, 47 (July, 1966), 7, 300-303. For a history of the Iowa State Horticulture Society see pp. 257310 of the same volume. See Philip D. Jordan's "In the Shade of the Old Apple Tree," The Palimpsest, 55 (May-June, 1974), 3, 66-77 for an interesting account of apple-growing in Iowa up to 1920. 
the Fountain Hill Nursery at Muscatine in 1850 . He operated this nursery for over thirty-five years. ${ }^{2}$

The first apples planted in Iowa were either seedlings or named varieties that were grown in the eastern states. One of the first printed lists of these old varieties is found in the early reports of the Iowa State Agricultural Society. Either at the state fair, or at the winter meeting of this society, a prize was offered for the best essay on some agricultural subject. At the 1857 fair held at Oskaloosa, Suel Foster, at that time president of the Muscatine County Farmers Club, wrote an essay on the results of a questionnaire he had sent to fruit growers in Iowa, Illinois, and $\bar{W}$ isconsin. One reply from a grower in northern Illinois listed some twenty-five varieties according to their relative hardiness. Better known of these were Baldwin, Gravenstein, Roxbury Russet, Northern Spy, Spitzenburg, Rhode Island Greening, Yellow Bellflower, Benoni, Tolman Sweet, and Red June. These are all old eastern varieties and several can still be found in some Iowa orchards.

Another fruit grower sent in a list of his favorites, listed by time of ripening as Early Harvest, Red June, Sweet June, Maiden Blush, Snow, Rambo, Fulton, Tolman Sweet, Jonathan, White Winter Pearmain, Winesap and Janet.

At the 1858 fair, a nurseryman, a Mr. Seevers from Oskaloosa, stated that if he was confined to planting only twenty varieties he would choose the following, which he lists in order of ripening: Red June, Sweet June, Red Astrachan, Early Pennock, Pound Sweeting, Ramsdall Sweet, Early Harvest, Smith Cider, Tolmans Sweeting, Fall Wine, Roman Stem, Westfall's Seek-NoFurther, Wells Sweeting, Sweet Romanite,Carthors, White Winter Pearmain, Rauls Janet, Winesap, Oskaloosa, Willowtwig.

Also given at the 1858 essay contest was a paper on "The Apple" presented by James Smith, one of the first fruit growers in Polk County. This discussion of the apple includes not only a brief report on seventy-two different varieties but also give directions on planting and culture methods. This essay was perhaps the first article on the culture of the apple ever to be printed in the state.

${ }^{2}$ Foster made a vigorous appeal to the Iowa Legislature to establish a college for young people from farm and labor families. With the help of a few others, he persuaded the 1853 Iowa Legislature to pass a bill to establish such a college. Foster was appointed to the committee that chose a site in Story County near the town of Ames. 
The variety lists given above are the first to be found in print in old Iowa records. They contain but a few of the better known varieties of apples planted in Iowa prior to the Civil War. It is interesting to note that many of these varieties are still grown. The most important of all of these is the Jonathan, still one of Iowa's three leading varieties.

\section{Increased Demand for Nursery Stock}

The nurseries mentioned were but a few of the many started before and immediately following the Civil War. The early settlers demanded timber trees, fruits and osage orange for fences. The earliest settlers tried to find land with some native timber on it. Those who came later settled on the prairies and had to grow some of their own timber. When the Osage Orange became popular, especially in Southern Iowa, several large nurseries were started to meet the demand. Also the early farmers demanded fruits of all kinds for home consumption. Soon after settlement started, dozens of tree salesmen travelled the rural areas selling nursery stock. Some represented eastern nurseries, but many were on their own. They would get as many orders as possible, then often buy the culls from some established nursery and label the trees with the names of the varieties listed on each order. It often took several years for the planter to find out he did not get what he ordered. Responsible Iowa nurserymen and the horticultural societies in the state did their best to counteract the damaging work of these itinerant salesmen. Those desiring nursery stock found that they could be assured of both trueness to name and quality by patronizing a local nurseryman.

As time went on, considerable change took place in the nurserry business. Along in the 1870 s there were as many as eight to ten small nurseries in many counties. Today there are very few. But there are a number scattered over the state that were started over a 100 years ago and still owned by the third and fourth generation of the families.

There has also been a change in the type of nursery. In southwest Iowa several very large wholesale nurseries have developed. Some do not do retail selling, but grow the plants sold by smaller nurseries, garden centers and large department stores that have nursery departments. These large wholesale nurseries grow much 
of their stock in the parent nursery, but also will often grow certain items in other locations where that item can best be grown. For instance, a nursery in Shenandoah will grow hundreds of acres of stock on its nearby farms, but will produce its roses in Texas or California, grapes in New York, and seedling apples in Washington. Since World War I, there has been considerable change in the type of plants grown in these nurseries. Up to about the turn of the century, about $90 \%$ of their inventories were fruit plants, with $10 \%$ ornamentals. With increased unbanization, this has been completely turned around. Today over $98 \%$ of the demand for nursery stock is for ornamentals. However, there are still nurseries that specialize in fruit trees. As late as 1965 around four million apple trees were produced annually in Iowa by these large wholesale nurseries.

Young apple trees growing in the nursery now might all look alike to most people. But to those who work with them, trees of different varieties have their own individual characteristics. About 1920 a scientific pomologist in Massachusetts, Dr. J. K. Shaw, learned to identify nursery trees by their leaf and twig characteristics. Today, in most states where there is considerable production of apple trees, there are trained men, usually connected with a University Department of Horticulture, who each summer walk the miles of nursery rows of apple trees to certify that they are true to name. For the past ten or fifteen years Iowa has had such a man, A. E. Cott of the Iowa Agricultural Extension Service.

\section{What Is An Apple Variety?}

A variety (of apple) is a tree and its fruit that was grown from a seed, given a name by someone and propagated asexually. Propagation of the apple tree is done by either grafting or budding. Most plants produce seed, and the common method of securing new plants is by planting the seed. Most seedlings, although differing slightly from each other, are quite similar to the parent plant. Some plants, however, produce seedlings that differ in many ways from the parent plant. The apple is very heterozygus, which means it will not come true from seed. If one took all the seed from fifty Jonathan apples, planted them and allowed them to grow to produce fruit, each tree would produce a different fruit, none of which would be identical to the parent Jonathan. 
Such trees are called seedlings. Every apple variety that ever existed started as a seedling.

Prior to about 1875 , out of tens of thousands of seedling apples, perhaps three or four thousand were named and propagated. Most of these soon disappeared from cultivation. Many were only known locally. Some have been propagated and grown for several hundred years. And then a few, such as the Delicious and the Golden Delicious, have, in 100 years or less, become the leading, most planted varieties in the world.

Up until about 1950, the word "variety" was the only term used in regard to an asexually propagated plant. But "variety" was also used to describe a sexually produced plant such as the Detroit Dark Red Beet or Grimm Alfalfa. It also has other meanings. As a result, botanists and certain scientific people have coined the word "cultivar" to replace the term "variety" when referring to asexually reproduced plants. Today the term "cultivar" is found more and more in scientific papers, but the word "variety" is still used by most nurserymen and fruit growers. No doubt, sometime in the future the term "cultivar" will come into common use.

Soon after fruit trees were first planted in Iowa, there was a very severe winter in $1842-43$ that killed many trees. This was the first so-called "test winter" recorded in Iowa. The summer of 1842 had been very dry, followed by a very cold winter. At Iowa City it was below zero every day during March. The Mississippi River above Keokuk was frozen from November 1842 until April 8,1843 . The trunks of many apple trees split open due to drying out caused by the long period of intense coid.

This cold winter was followed by others that did considerable damage. The most serious test winters that have been recorded in Iowa were in $1855-56,1865-66,1872-73,1873-74,1874-75,1876-$ $77,1882-83,1884-85,1898-99,1911-12,1917-18$, and 1925-26. The most serious damage of all was caused by the November 11 , 1940 blizzard. Since then very little winter injury has occurred. In western Iowa entire orchards were killed by this storm when the temperature dropped from $70^{\circ}$ at 7 a.m. to $0^{\circ}$ at 7 p.m. on that day. Coupled with this was a late growing season with considerable rain and no frost. As a result, the wood in the trees had no chance to mature. The sudden temperature drop froze the most immature wood. The damage, although showing in many parts of 
the tree, killed the inner bark at the ground line on the trunks, in many cases girdling the trees. ${ }^{3}$

Back in 1842, comparatively few apple trees had been planted in Iowa and most of these were in the eastern part of the state. Both nurserymen and orchardists found that there was considerable variation in the damage done to different varieties. They found that many varieties they had brought from the East were severely injured or killed, while other varieties came through the winter showing little or no injury. As a result, they listed or classified the varieties as "hardy," and "half hardy," or "tender" for various sections of the state. Only the most hardy could be grown in northern Iowa.

As the test winters continued to occur, many smaller fruit growers became discouraged. "Iowa is not a place to grow fruit" was heard on all sides. Many growers did not replant after their trees were damaged. But there were some who did not give up. They studied the problem and replanted, using varieties they had found relatively hardy. They also tried to develop or introduce new varieties that might prove to be more hardy. Whenever a group of fruit growers and nurserymen got together, the subject of the hardiness of this or that variety was the main topic of discussion.

One of the first attempts to classify apple varieties according to hardiness of trees was prepared by David Leonard, a nurseryman near Burlington, in $1866 .{ }^{4} \mathrm{He}$ prepared this list from twenty years of careful observation. He listed Hardy for Southeastern Iowa-Summer Pearmain, Lowell, Summer Pippin, Fall Janet, Winesap, Roman Stem, Jonathan, Ben Davis, Yellow Bellflower, and Northern Spy; Semi-Hardy for Rambo, Summer Queen, Fall Wine, White Winter Pearmain, and Rome Beauty; Tender for Maiden Blush, and Fall Pippin.

Fifty years after this list was prepared many of these varieties had passed out of cultivation. I first became acquainted with apple varieties in 1914 and remember a few that are still found in

${ }^{3}$ In general, there are two types of weather conditions that will injure or kill woody tissues of the more tender types of plants. These are a long, extremely cold winter usually preceded by a dry summer and fall, or a rainy summer and fall with mild fall temperatures that prevent the hardening of the wood followed by a suddent drop in temperature.

${ }^{4}$ Proceedings, Iowa State Horticulture Society, 1866-67, 54. 
some Iowa orchards, such as Lowell, Roman Stem, Ben Davis, Yellow Bellflower, Northern Spy, W. W. Pearmain and Maiden Blush. A few on Leonard's list are still grown commercially in Iowa or some other part of the country-the Jonathan, Winesap, and Rome Beauty. It must also be pointed out that the varieties listed above were but a few of the many varieties grown in Iowa at the time of the Civil War.

It was concluded that the trees of many desirable varieties were none too hardy. Much of the injury caused by extremes in weather conditions occurs on the trunk and on the inside of the main crotches of the tree. To counteract this, the practice of grafting the more desired, but winter-tender varieties, into the trunk or on the branches of a small winter-hardy variety of apple was developed. One hundred years ago this grafting was done some four to six feet above the ground on the trunk. More recently, budding has been used more than grafting. A nursery tree of a hardy stock is planted and allowed to grow for two or three years until it is well branched. Then in the summer, buds of the desired variety are inserted in the main branches some twelve to fifteen inches from the trunk. In this way the trunk and main crotches of the tree are of the hardy variety. Today the Hibernal is the favorite of several so-called hardy understocks used. Today many Iowa orchardists have used this method for the more tender varieties they grow, such as Jonathan and Delicious.

Apple varieties vary from each other in endless ways. Therefore terms have been developed that are used in describing both the fruit and the tree. Space does not permit a detailed discussion of all the terms used in describing an apple, but a few of the more common terms will be mentioned.

First, the fruit ripens in different seasons. So a variety is classified as a summer, fall or winter apple. These terms vary depending on where the fruit is grown. Nationally, the Jonathan is classed as a fall apple. In Iowa the northern limit for this variety is called a winter variety. The fruit may vary in color, shape, size, texture and flavor. Other variations occur in length of stem, and the shape and depth of both the stem and blossom ends of the fruit. A person who is able to identify a variety usually looks for some external characteristic or a combination of characteristics that are common to the individual variety. Some varieties are easy to identify, others more difficult, as their fruits often look a great 
deal alike. It is easy to tell a Northwestern Greening from a Delicious, but sometimes highly colored specimens of Jonathan, Winesap and King David look nearly alike.

Identification is much less a problem today because we have fewer varieties than years ago. Eighty to a hundred years ago, when there were so many different kinds, it is said that Col. G. B. Brackett could name nearly 400 different apple varieties when presented with single specimens.

Many of our older apples were called sweet apples because of their decided sweet taste. Our older orchards usually contained several of these. Today they have nearly passed out of cultivation. About the only one that is still planted to a limited degree is the Tolman Sweet. But many people today have never tasted a socalled sweet apple. Our older home orchards also contained a number of crab apples. These were grown for making jelly and for pickling. About the only one found in nursery catalogues today is the Whitney, which originally was called Whitney \#20. It is a large crab still found in most parts of the state. Varieties that ripen in the summer or early fall will not keep very long and must be used at once. They are mostly used for pies or sauce. The length of time winter apples can be stored varies a great deal. In the old days, when apples were stored in cellars and caves, there was a need for varieties that would still be useable in April and May. There usually were rather small, very firm apples with thick or rough skin that prevented drying out. One class of these were the Russets, several varieties of which were found in many early Iowa orchards. The skin was a bronze or green color and was very rough and russetted. Two of the more common of these were the Golden Russet and the English Russet. The old russet apple is seldom seen today. Still found, but little grown, is the Ralls which has several other names such as Janet, Jeniton, Rawles Janet, etc. It is a rather small, poorly colored apple with long keeping qualities. Also of this type was the Little Red Romanite which practically passed out of use fifty years ago. Another very popular apple that kept quite well in the caves and unheated, earthen cellars of yesteryear was the Ben Davis.

But times changed. Commercial cold storage developed in Iowa about the turn of the century. Furnaces replaced the old Coles Hot Blast, making the cellar too warm for keeping apples. Today, in the fruit growing regions of the country, we have 
controlled atmosphere (CA) storage under which such varieties as Delicious and Golden Delicious can be put in storage at harvest time and be removed as late as the following July in perfect condition. As yet there are no CA storages in Iowa.

The tree itself is important. As mentioned above, winter hardiness is of primary importance. The grower needs annual, heavy production of large-sized, well-colored fruit. Some varieties, like the Wealthy, are noted as alternate year bearers; others such as the Rome Beauty, and often the Delicious, are late in coming into production. It takes several years longer until they will produce a profitable crop.

\section{Improvement of the Apple}

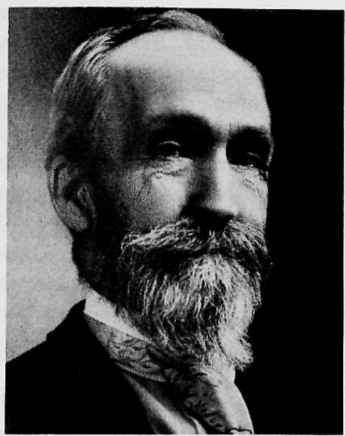

Courtesy of Iowa Historical Department. Division of Historical Museum and A rchives G. B. Brackett

In spite of all the research used to improve the apple, the fact remains that nearly all of the varieties grown today have originated as chance seedlings. The two such leading varieties grown in the commercial orchards of the United States today are the Delicious and the Golden Delicious. The former was found as a chance seedling growing in a farm orchard in Madison County, Iowa and the latter was found growing on a mountain side in West Virginia.

In a few cases a variety originated as a "selected seedling." The best example of this is the Wealthy. Peter Gideon, a pioneer settler near Excelsior, Minnesota, found the varieties available to him would not stand the cold winters of Minnesota. About 1860 he sent $\$ 15$ to a fruit grower in Bangor, Maine for some seed of the Cherry crab. He knew that this crab was very hardy and he hoped trees from its seed would prove hardy in Minnesota. He planted the seed in his garden and from the resultant trees that produced fruit he selected one that he thought produced a superior fruit. He named it the Wealthy in honor of his wife. The 
Wealthy was first described about 1869 in The Western Farmer. Iowa fruit growers were among the first to try out this new variety. After several years of trial it was accepted. The tree proved to be very hardy and the fruit was not only attractive, but an excellent cooking apple. It was used in making apple butter and cider for a hundred years. Several years after the Armistice Day Storm of 1940 in western Iowa, this variety was about the only one left. It is still being grown all over the Midwest in home orchards and on the town lot where there is room for one apple tree. It is still listed in most Iowa nursery catalogues.

Another method of fruit improvement developed during the latter part of the 19th century: the sexual crossing of two varieties of known characteristics. Under natural conditions the female parent of an apple seed is known, but the male, the pollen parent, is not known. But by removing the stamens on a flower before the pistil is receptive, and covering the flower with a bag to keep out pollen in the air and insects, and then putting pollen from a known variety on the tip of the pistil with a brush, then rebagging, seed will be produced where both parents are known. Where practiced in Iowa, the main objective was to cross a variety producing a high quality fruit with the pollen from a very hardy variety.

As early as 1887 Professor J. L. Budd at Ames had experimented with this method by hybridizing his imported Russian varieties with various American varieties. ${ }^{5} \mathrm{He}$ had several of his students learning the techniques of crossing the apple. No doubt $S$. A. Beach, who received a B.S. degree under Budd in 1887, and later his M.S. degree, was one of them; and when he joined the staff at the New York Agricultural Experiment Station at Geneva, he became intensely interested in this method of apple improvement.

Charles G. Patten, a nurseryman at Charles City, was one of the pioneers who used this method. He made hundreds of crosses and was a firm believer in this method of fruit improvement. ${ }^{6} \mathrm{At}$ the 1905 meeting of the American Pomological Society in Kansas

${ }^{5} \mathrm{He}$ made a trip to Russia in 1882 and brought back about 300 varieties of fruit, mostly apples. These he propagated and sold all over northern and central Iowa. As they came into bearing, they ripened in the summer instead of in the late fall, as they had under the shorter growing season of Russia. None proved of much value in lowa.

'Proceedings, Iowa State Horticulture Society, 1941, 28-32. 
City he exhibited the first collection of crossbreed apples in the United States. Among the varieties he introduced were Patten Greening, Eastman, Brilliant and also the Patten pear. As Mr. Patten became too old to carry on his work, in 1917, the Agricultural Experiment Station at Iowa State took over several acres of his crossbreed material at Charles City and continued his work for several years. This substation at Charles City was operated by the Pomology subsection until the death of Mr. Patten in 1921, at which time the more important breeding material was moved to Ames.

In 1905, S. A. Beach was appointed Head of the Department of Horticulture and Forestry at the Iowa State Agricultural College in Ames. He had been the Horticulturist at the New York Agricultural Experiment Station at Geneva, New York where he had just completed The Apples of New York, in which he described about 1200 different varieties. ${ }^{7}$ Soon after he arrived, Beach established a large apple breeding project. Between 1906 and 1920, hundreds of apple crosses were made. He was assisted by several of his staff, especially Thomas J. Maney and later by Harvey L. Lantz.

The crossbreed seed was planted in nursery rows, and after a year or two was grafted into the branches of young trees. Each tree in this orchard contained four or five different crosses. Fruit specimens were gathered, properly labelled and examined carefully for their value as new varieties. While a student in 1915, I had the job of gathering the fruit as it ripened and carefully labelling it.

Crossing on an even larger scale was started again in 1917 and continued for many years. Since 1906, between 15,000 and 20,000 crossbreed apple seedlings have been grown by the Pomology subsection. Starting in 1918, this project was under the direct supervision of H. L. Lantz. Professor Beach died in 1922 and he was replaced by B. S. Pickett in 1924. At this time the Athletic Department secured the old horticulture orchards to use as a golf course. A number of these old crossbreed apples are still found on the University golf course. The Horticulture Department was given a new farm just southwest of the campus. Many acres were

'S. A. Beach, The Apples of New York, 2 vols. (New York: Department of Agriculture, 1905). 
given over to the apple breeding project, containing second and third tests of these cross-breed apples, in addition to new crosses. Subsequently, test orchards of the best of these crosses were planted at several of the State Hospitals.

Before Professor Beach died, he named and introduced eleven of his best selections. Among these were Edgewood and Secor (SalomeXJonathan), Sharon (McIntoshXLongfield), Joan (Anisim XJonathan) and Hawkeye Greening (Vermont Seedling unguarded). In giving the parentage of a cross, the female parent is always named first, followed by the pollen parent. These varieties proved to be the most popular of the eleven first introduced by Professor Beach. They have not only been planted in Iowa, but in many sections of the country. The Sharon is still being grown, fifty years after its introduction. It is an excellent eating and cooking apple. Its greatest fault is its striping and its general lack of good color.

As part of this apple breeding work, many crosses between Jonathan and Delicious were made. Here the stress was on the production of a very high quality fruit with less emphasis on tree hardiness. In 1958, Mr. Lantz introduced the Jonadel which received a good reception by Iowa orchardists. After Mr. Lantz's death in 1958, the Department of Horticulture (in 1966) introduced the last of these cross bred apples, the Chieftain (Jonathan XDelicious). This apple breeding project, in existence for sixty years, was discontinued after the introduction of the Chieftain.

\section{The Iowa State Horticulture Society}

The most important group in the state to gather, digest and disseminate information on apple varieties, especially during the period from 1866 through 1940 has been the Iowa State Horticulture Society. This society was organized in Iowa City June 26, 1866 by a group of twenty-eight men, mostly nurserymen and fruit growers. It has been in continuous existence ever since, for a period of over 108 years. It was the first society to deal with a specific aspect of agriculture organized after the Iowa State Agricultural Society had been formed in 1854. Mark Milier, then editor of the Iowa Homestead, was the man responsible for getting the Horticulture Society started. At the organizational meeting Dr. James Weed, a dentist from Muscatine, was elected president and Mark Miller, Des Moines, secretary. The Iowa State Horticulture Society printed an annual report from 1866 until 1955, 
when the printed report was discontinued. These ninety annual proceedings provide a rather complete history of Iowa horticulture.

The early membership of the society was mainly interested in fruit growing and the nursery business. For many years the principal topic of discussion was what fruit varieties should be recommended for planting in the various sections of the state. The very first report, in 1866, contains a list of apple varieties recommended for planting in southeastern Iowa. Soon a list was developed of varieties to be planted in southern, central and northern Iowa.

Through the years, at each annual meeting much time was devoted to discussing the various members' experiences with this variety or that variety, and haggling over whether a certain variety should be added or removed from the recommended lists.

During the period from 1896 until 1919 the secretaries listed the names of all the different varieties discussed at each annual meeting. In 1896 a total of 288 apple varieties were listed. This number gradually dwindled, until by 1919 only thirty-nine varieties were mentioned. By then many of the older varieties were not being planted. After World War I, Iowa fruit growers knew the best varieties to choose for their commerical plantings. But, besides planting their principal varieties, they usually included a few trees of newer sorts to see how they produced under their particular conditions.

\section{Fruit Displays at the Iowa State Fair}

Premiums on fruit displays have been offered at every state fair since the first fair was held in Fairfield in 1854. At the early fairs the fruit displays consisted of the best and largest collection of apple varieties, best fall cooking and eating apple, and best winter cooking and eating apple. Gradually premiums on other fruits were added. Apparently local exhibitors complained that they could not compete against the more experienced fruit growers, so two categories were established, professional and amateur. The highest premium was $\$ 10$, awarded to the best collection of varieties. Often an exhibitor would display as many as 150 to 200 different varieties.

It was not until the 1872 fair that premiums were offered on a 
named list of varieties. That year the list included twenty-seven of the more commonly grown apples. At later fairs this list was increased. In more recent years premiums have been offered on only seventeen named varieties plus three other classes listedoptional summer, fall, and winter varieties. In each of these an exhibitor may enter as many other varieties as he desires.

In the early fairs the state was not divided into districts. But soon exhibitors from northern Iowa found they could not compete against exhibitors from southern Iowa. Their fruit was not as well developed. As a result, today the state is divided into southern, central, and northern districts for some classes, while certain other classes are opened to exhibitors from any place in the state.

The largest displays of apples and other fruits, especially plums and grapes, were found at the fairs held prior to World War I. They have been diminishing in size, especially since 1940 but still the size of these exhibits amaze fair visitors. A common comment heard is "Why can't I buy apples like these in my local grocery store?"

\section{Colonel Brackett and His Wax Apples}

Fruit growers, like most other producers of farm products, have always been interested in displaying their fruits. The earliest exhibit of Iowa apples on record was at a meeting of Western Fruit Growers at Burlington in 1845. Since then hundreds of exhibits of fruits, vegetables, and flowers have been staged at county, state, regional, and national fairs and expositions. At the time of the Centennial Exposition held in Philadelphia in 1876, the state of Iowa decided to send an exhibit. The Iowa State Horticulture Society agreed to send an exhibit of apples and a display of native and introduced species of trees grown in the state. The exhibit of native woods was prepared by $\mathrm{H}$. $\mathrm{H}$. McAfee, the first professor of Horticulture and Forestry at the Iowa State Agricultural College at Ames. Colonel G. B. Brackett of Denmark, Iowa had charge of the apple exhibit.

Since the exposition opened in early summer, before any apples had ripened, Mr. Brackett with the help of a local artist, a Mrs. Greenwood, made up a collection of 1,000 specimens of over 300 varieties of apples that were being grown in the state at that time. They were life-like reproductions and so perfectly made they were difficult to tell from the real fruit. These were taken to 
Philadelphia and displayed during the early weeks of the exposition. As the apple crop ripened in Iowa, growers sent Colonel Brackett a total of sixty barrels of real apples to replace the wax apples. This collection of apple models made a nation-wide reputation for the Colonel. During the next several years he was asked to make similar exhibits in New Orleans and twice in Paris, France. $^{8}$

The wax apples were displayed for many years on the ground floor of the State Capitol in Des Moines. Most of the collection was discarded in 1924 when the office of the Secretary of the State Horticulture Society had to move to smaller quarters. A few were saved and are now on display in the State Historical Museum in Des Moines. This one-hundred-year-old display will be on loan to the Bicentennial Exposition in Philadelphia during 1976.

\section{The Pioneer Orchard on the Iowa State Fair Grounds}

In 1967 the Secretary of the Iowa State Fair, Kenneth Fulk, established a Pioneer Orchard to show some of the first apples planted in Iowa. It is located just northwest of Pioneer Hall on the state fair grounds. This orchard consists of twenty-four trees of Hibernal, which was planted as a hardy understock. Over a period of four years each tree was budded to one of the following varieties: Anisim, Ben Davis, Black Annette, Black Gilliflower, Fameuse (Snow), Golden Russet, Huntsman, Longfield, Maiden Blush, Malinda, Northern Spy, Oliver (Senator), Rambo, Roman Stem, Salome, St. Lawrence, Seek-no-further (or Westfield), Tolman Sweet, Tompkins King and Wolf River.

\section{Comments on a Few Apples Grown in Iowa}

Oldenburg, more commonly called Duchess: This summer apple was grown in Europe for over 150 years before it was brought to America. It has been one of the leading summer apples grown in Iowa orchards since the state was first settled.

Yellow Transparent: A Russian variety introduced into this country in 1870 , it was one of the earliest apples to be used. It is picked green when large enough for use and made into sauce. It is

'The story of Colonel Brackett and his apples of wax has been told by Kent Pellett, Annual Report, Iowa State Horticulture Society, 1941, 24-27. 
of little value when ripe. Since its introduction, Yellow Transparent has been mixed with the Early Harvest, which had been grown for many years. The fruits were quite similar and difficult to tell apart. By 1920 the Early Harvest was little known.

Wealthy: Still grown in most home orchards and is one of the best for back yard planting.

Whitney Crab: This is the principal crab apple grown today. It is used mainly for spicing and pickling. Crab apples are little grown today, but the Whitney is still found in many Iowa home orchards.

Grimes: More commonly known as Grimes Golden. Grimes was the leading yellow, early winter apple grown in southern and central Iowa until the Golden Delicious replaced it. It is a high quality eating and cooking apple, but the skin is rather thin and it is easily bruised. Until the late 1940 s it was grown commercially in Iowa and can still be found on the market every fall. The Golden Delicious has become the leading yellow apple, but the Grimes is still grown.

Jonathan: Has been grown in Iowa since its earliest settlement. About 1900 it became Iowa's leading commercial apple, especially in central and southern Iowa. In more recent years the Delicious has been gaining in favor. It reaches its perfection at its northern limits of growth, which is central Iowa. When planted north of central Iowa the tree lacks winter hardiness. At its northern limit the fruit develops high color and better keeping quality. In Iowa it is usually considered a winter variety while nationally it is classed as a fall variety.

Hibernal: A very hardy variety introduced from Russia in 1870. The tree is a vigorous grower and can be grown at the northern limit of apple production. The fruit ripens about September 1st in central Iowa, is rather large, yellowish in color with a red blush. It is a fair cooking apple. But it usually is not grown for its fruit but as a hardy framework on which more tender, higher quality varieties may be top worked. In Iowa it was used for top working soon after it was introduced. It and Virginia Crab have been the two favorite hardy stocks used in Iowa and the Midwest. But a virus has invaded the Virginia Crab which now makes the Hibernal the principal stock used. The Pioneer Orchard on the Iowa State Fair Grounds is all top worked on Hibernal.

Northwestern Greening: This variety was found in Wisconsin 
about 1872 and it was soon introduced into Iowa where it has been grown for a hundred years. The tree is large and hardy, so it is grown more in central and northern Iowa. The fruit is large and mostly green although it does turn yellow, and during some seasons develops a light red blush on the sunny side of the fruit. The tree will become quite large and is usually an annual bearer. The quality is fair, and it makes an excellent pie, sauce, and baking apple. It is still grown on a commercial scale in some central Iowa orchards and in many home orchards.

Ben Davis: The barrel filler. Ben Davis was the leading commercial apple grown in Iowa and further south from about 1875 until 1915. The fruit is usually large, well colored with a darker colored stripe. The skin is thick and withstands bruising which made it ideal for packing in barrels. The place of origin of this apple is not known; Kentucky, Tennessee, and Virginia have all claimed to have the original tree. By 1900 it was the leading commercial apple south and west of the Baldwin belt. It was grown from Virginia westward through Arkansas, Missouri and southern Iowa. It was the barrel apple and was in great demand in the days of earthern-floored cellars, before the days of furnaces. A barrel or two, stored under these conditions kept the average family in fruit throughout the winter. Millions of apple pies and dishes of apple sauce have been made of Ben Davis. Soon after the Civil War two tree sports of the Ben Davis were found and propagated. They were the Gano and the Black Ben. The original trees were found in different places. Their fruits, instead of showing the darker stripes in the red color, were solid red with practically no striping. In general they produced a crop with a higher percentage of color, and many growers planted one of these rather than Ben Davis.

In 1904 Iowa produced its largest crop of apples and most of them were Ben Davis. Center of the heaviest plantings was in southwest Iowa, especially in Mills County. The largest orchard ever planted in the state consisted of 800 acres, planted by John Y. Stone near Glenwood. It was made up of mostly Ben Davis. The 1910 Census reported Iowa's apple crop (for 1909) as a total of about 500,000 barrels, while that of 1894 as $1,500,000$ barrels. It was not long after 1900-1910 that the market started to demand a higher quality apple than the Ben Davis. Living conditions were 
changing. Instead of the Coles Hot Blast stove in the living room, furnaces were being installed in basements with a cement floor. The cellar was too warm and too dry to permit long storage of fresh fruit. Also commercial cold storage was becoming more available. Coupled with this, newly planted orchards in the Northwest were starting to produce. The long distance haul to market made it profitable to pack carefully and ship only the highest quality fruit. The western wooden apple box became a common sight on midwestern and eastern markets. As a result, the Ben Davis was doomed. ${ }^{9}$

The demise of the Ben Davis was hastened by a disease called Blister Canker that killed many trees. The Ben Davis was especially susceptible to this disease. The cankers develop on the trunk and main branches of the tree, eventually girdling them. I remember spending many hours digging out these cankers with a chisel and mallet in 1916. My efforts were mostly in vain.

The Delicious: The Delicious apple is today the leading apple variety grown in Iowa, the United States, and the world. The original tree still stands on the farm now owned by Margareta Tracy, and her brother Raymond E. Tracy, which is located a few miles northeast of Peru, Madison County, Iowa. It was found growing in the orchard of Jessie Hiatt in 1870. In 1893 it was brought to the attention of the Stark Brothers Nursery, Louisiana, Missouri which purchased the propagation rights and named it the Delicious. Since 1893 they have sold millions of trees of this original chance seedling Delicious, or of several of its bud sports. ${ }^{10}$

In 1922 several historical and horticultural groups dedicated a monument to the original Delicious tree. This monument is a

'The apple barrel was the principal container used in shipping apples from the time commercial orcharding started to develop in the 1830 s and 1840 s. Prior to World War I Iowa growers used the barrel, with a few packing their better varieties in a Western Apple box. The barrel started to be replaced by the wooden bushel basket. By 1940 the bafrrel had almost completely disappeared. By 1960 both the wooden box and the bushel basket were replaced by cardboard boxes due to the high price of wood. Today even smaller containers than the bushel are used because of the changes in living conditions among our increasing urban population.

${ }^{10}$ For a more complete story of the Delicious the reader is referred to the program at the dedication of a monument to the original Delicious apple tree, Annual Report, Iowa State Horticulture Society, 1922, 84-95, and "Jessie Hiatt and the Delicious," The Stark Story: 150 Anniversary Stark Nurseries (St. Louis: State Historical Society of Missouri, 1966), 38-41. 
large boulder and stands in the city park in Winterset, Iowa. The Armistice Day Storm of 1940 killed the original tree to the ground, but later several sprouts grew from its roots. Mainly through the personal efforts of Robert S. Harrick, for many years secretary of the State Horticulture Society, two trees were allowed to develop, and are still producing fruit. Although this tree has had two tops, it can be said to be over one hundred years old.

\section{Apple Varieties Grown in Iowa Today}

Presently the three leading varieties grown by Iowa's commercial fruit growers are the Delicious (or its bud sports), Jonathan and Golden Delicious. No doubt they will continue to be the leading varieties for many years to come. All three have exceptional quality, fine color and size, and satisfactory keeping quality. They have high eye appeal when displayed at the local supermarket. Iowa growers also grow many other varieties. They dispose of most of their crop locally, from a roadside stand or from a storage sales house. To spread out their marketing season they grow some summer and fall varieties as well as other winter sorts that are used more for cooking or pie apples. They try to open their sales in early August when they have such varieties as Yellow Transparent, Duchess, Melba, Beacon, Wealthy, Sharon and many others available for their early customers. Many Iowa growers now have a small mechanical cold storage in which to keep their fruit in good condition until sold.

Fruit growers always want to try out the newer varieties as they are introduced, and most will plant a tree or two of these new sorts to see how they will produce under their particular growing conditions. Perhaps the most outstanding of these is the Golden Delicious, which was discovered growing on a mountain side in West Virginia in 1914 and introduced by Stark Brothers. In less than fifty years time this variety has risen to become the second or third most important variety in Iowa and the United States. Nationally it competes with McIntosh; in Iowa with Jonathan.

The perfect apple has not yet been found-and no doubt never will be found. So growers, nurserymen and fruit breeders will continue on the lookout for a better chance seedling or a product of some apple breeding program. 


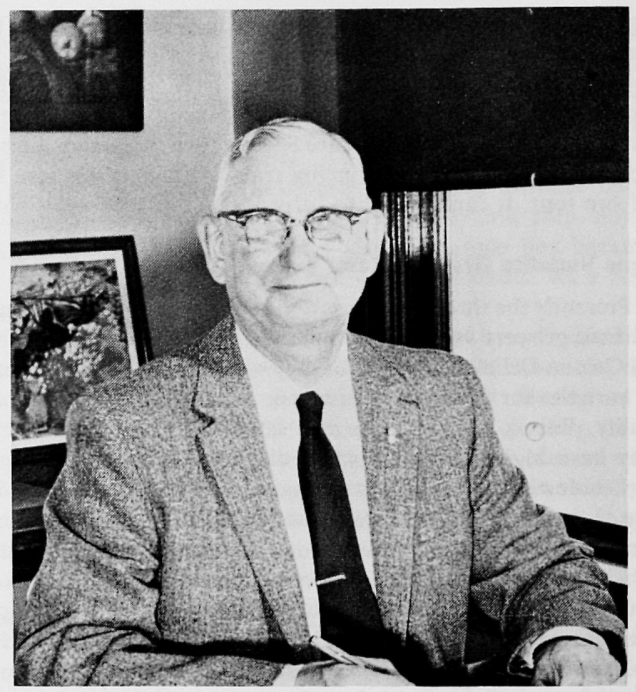

Harry E. Nichols

Courtesy of author

I first started to study and learn apple varieties in 1914 and can remember dozens of varieties that were common then that have since passed entirely out of cultivation. I have also seen many new varieties introduced, some of which were grown for a short time and then disappeared, others that rapidly became very popular and have, by their superior qualities, forced earlier favorites off the market.

The apple growing industry has undergone much change in recent years. Commercial orchards are becoming larger. As more and more of our apples are sold through the supermarket, the home orchard that used to be found on nearly every Iowa farm is disappearing. 
Copyright of Annals of Iowa is the property of State of Iowa, by \& through the State Historical Society of Iowa and its content may not be copied or emailed to multiple sites or posted to a listserv without the copyright holder's express written permission. However, users may print, download, or email articles for individual use. 